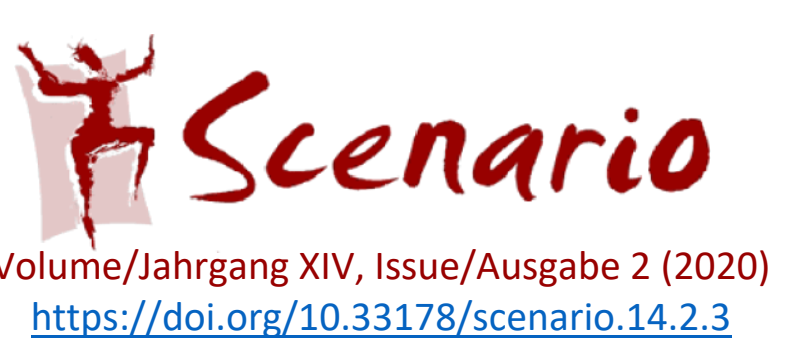

\title{
Getting Them Back to Class: A Project to Engage Refugee Children in School Using Drama Pedagogy
}

Magda Vitsou, Maria Papadopoulou, Eleni Gana

The paper presents aspects of a drama based six months' project with refugee children during their first period of schooling in Greece. The project ${ }^{1}$ aimed to investigate whether drama sessions could facilitate second language learning, strengthen children's participation in classroom communication and enhance interaction among pupils and teachers with few shared language resources in an attempt to provide them with positive experiences.

Drama strategies were used to provide a joyful and welcoming environment and boost children's communication skills. In most cases, drawing and painting, music and art were also used to support the drama activities. According to the research results, the children made use of various linguistic and non-linguistic resources (mother tongue, English, Greek, gestures, facial expressions, body movements, eye contact etc.) for interaction and self-expression and they developed positive feelings towards their classmates, their tutors and schooling. The language, which was produced through drama, was employed within a social context and was appropriate to the specific participants, setting and topic. Thus, the students were engaged in purposeful and meaningful communication. The findings from this case study highlight the beneficial effect of drama pedagogy on refugee children's second language learning and on their socialization in the school environment.

\section{Introduction}

From 2012 until today, hundreds of thousands of displaced people from Asia and Africa who fled home due to conflicts, economic devastation, human rights violation and persecution, have been crossing Greece in search of a better future in Northern Europe. Considering the fact that more than one third of the refugee population were children, education was of outmost importance. Even though education is a human right, which "enables access to other rights" (Sinclair 2007) and helps refugee children regain a "sense of normality" (Sinclair 2007: 52 ), evidence shows that many of them are at great risk of academic failure in the future (Hos 2014 and 2016, Jalbout 2015).

Given the negative impact of migration on their schooling but also on their physical and emotional health, it is primarily necessary to help newly arrived refugee children handle the challenges of the transition from life in their home country to the one in the host country (Dryden-Peterson 2017). Education in emergencies caters for the well-being of children,

\footnotetext{
${ }^{1}$ The project is briefly presented in Vitsou, Papadopoulou \& Gana (2019).
} 
adolescents and adults and plays a critical role in the resettlement of young refugees and in facilitating transition to citizenship and belonging (Cassity \& Gow 2005; Christie \& Sidhu 2002); therefore, education aims to restore hope and provide psychological support to those who suffer from "traumatic experiences" (Sinclair 2007; Papadopoulou, Tsioli \& Androulakis 2019). Consequently, creating a warm and welcoming environment and offering playful activities seem to be of pivotal importance. According to literature, drama could boost children's imagination, help them negotiate real and imagined worlds, and "engage in complex mental activity through focusing and directing their attention, using toys, puppets and other items in symbolic ways, so as to self-regulate their behaviour to develop extended play scenarios" (Bengochea, Sembiante \& Gort 2018: 39). Furthermore, at the time multilingual children are engaged in drama activities their sociolinguistic identities can be deployed. In such context, emergent multilinguals employ metacommunicative features and expand their languaging by using all their linguistic repertoires (Yun 2008).

The implementation of the official Greek plan for provision of education to refugee children started in January 2016 (Scientific Committee in Support of Refugee Children, 2017). At that time, most refugees were hosted in camps, in many cases in the vicinity of big cities, while only a small part of them resided in apartments inside the cities. According to the ministerial act issued in August 2016, afternoon preparatory classes called Refugee Reception and Training Structure (henceforth RRTS) exclusively for school-age refugee children aged 6 to 15 were to be established in many Greek state schools, neighbouring camps or places of residence, whereas kindergartens for preschool children were to be established inside the camps. Only students with a refugee background participated in those classes. The curriculum for refugee children included Greek as a second language, English, Mathematics, Sports, Arts and Computer Science.

Under the above circumstances, the Culture Lab of University of Thessaly organized and implemented a project called 'Literacy through Drama' (Vitsou, Papadopoulou \& Gana 2019). Given the limited shared language resources among teachers and refugee students, creative activities such as drama, music and art lessons were implemented (Vitsou \& Papadopoulou 2019) to contribute to the successful expression of meaning and knowledge (see Ntelioglou et al. 2014). In general, a pedagogy that focuses on drama acknowledges the wide range of modes for meaning-making (audio, visual, linguistic, spatial, performative, etc.), expanding language and literacy learning beyond traditional literacy practices (Aden 2017, Aden \& Pavlovskaya 2018, Bengochea et al. 2018, Franks 2014, Galante \& Thomson 2017, Ntelioglou 2011, Vitsou \& Papadopoulou 2019). 
The paper aims to contribute to/ the discussion on how a holistic approach like drama pedagogy may strengthen refugee children engagement in school communication and kindle positive feelings towards their new environment. A review of the literature on the role of drama pedagogy in teaching students with refugee experience is briefly presented in the first section, followed by the research questions that were addressed, the method used to collect and analyze data and the discussion concerning the impact of the project on learning and socialization.

\section{The impact of Drama Pedagogy in refugee's education}

Drama is an active approach to learning where participants identify themselves with roles and situations in order to be able to engage with, explore and understand the world they live in. This goes beyond language, as social interaction involves communication on multiple levels that cross cultural and language boundaries (Athiemoolam 2004, Chukueggu 2012, Cumming \& Visser 2009, Ntelioglou 2011, Naoko 2006, Souki 2019).

Specifically, drama 'liberates' the students from the confines of the conventional classroom environment and gives them the opportunity to draw on their own experiences and imagination. Drama pedagogy, as many researchers have pointed out, facilitates language acquisition not only in mainstream language classroom but in the second language classroom, as well (Bräuer 2002, Culham 2002, Desiatova 2009, Maley \& Duff 2005, Phillips 2003), focusing on both verbal and nonverbal modes of communication that exist in real life (Ntelioglou et al. 2014). According to Larsen-Freeman (1990), language is used within a social context and it is appropriate to the specific participants, setting and topic. Thus, communication is purposeful, meaningful, and "sociolinguistically appropriate" (LarsenFreeman 1990: 265). At the same time, drama has the potential to lower the learners' affective filter (Krashen 1988), helping them lose their inhibitions and overcome their shyness and anxiety.

Through drama conventions, children also make use of various semiotic resources to generate identities for themselves and others and to "create" spaces for peer culture (Bengochea et al. (2018).

Additionally, bilinguals are encouraged to use all language resources (in this case, native languages, English, Greek) and translanguaging practices in order to express themselves and "transfer" their repertoire of experiences and to (co-)construct their multidimensional identities with their peers and teachers (García-Mateus \& Palmer 2017). Translanguaging, according to Garcia \& Wei (2014: 65), 
involves multiple discursive practices in which bilinguals engage in order to make sense of their bilingual worlds. It goes beyond just code-switching and translation in order to encompass a process by which bilingual students perform bilingually in a myriad of multimodal ways.

\section{Description of the project}

The 'Language and Culture' Lab at the University of Thessaly designed and implemented a sixmonths' project called "Literacy through Drama", taking into account Krashen's affective filter hypothesis (1988) that second language learners show better linguistic outcomes within a collaborative environment where the fear of failure is absent.

The project was gradually developed over a period of 6 months (November 2016 -July 2017). The research team consisted of three (3) researchers and eleven (11) volunteer student teachers ${ }^{2}$ at the Department of Early Childhood Education, University of Thessaly. To support the student teachers involved in the project, extra courses on Drama techniques and Second Language Learning theories were organized in addition to already existing courses on intercultural communication. The participants were twenty (20) children (6-12 years old), eleven (11) boys and nine (9) girls, of Syrian (Arabic and Kurdish) origin. Their sociolinguistic profile was that of emergent multilinguals (García \& Kleifgen 2018); with Kurdish or Arabic as first languages along with some very basic skills in English and Greek language that many students have learned on their refugee route (Vitsou, Papadopoulou \& Gana 2019).

Engaging young people was considered to be beneficial in creating a more friendly environment and providing more instances for communication for all children (Vitsou \& Papadopoulou 2019). Within the broader goal to facilitate children's schooling in a joyful and playful way, the project aimed at enhancing children's involvement in school processes, strengthen their communicative potential by providing meaningful situations for the use of the host language and promote collaboration among peers and tutors and develop creativity.

In order to facilitate the smooth transition of children in schooling, the project started in November 2016, , two months before the official school program.. The activities took place daily, inside the camp where the children lived ${ }^{3}$, during an informal educational program organized by NGO's and University of Thessaly and included creative activities (music,

\footnotetext{
${ }^{2}$ The University of Thessaly organized many voluntary refugee support activities. As part of these activities, students participated in the program "Literacy through Drama". Attending the courses of Drama in Education and Introduction to Literacy was a prerequisite for student-teachers involvement. Additionally, student -teachers were under the consultation of other professional figures such as the university teachers and the schoolteacher. ${ }^{3}$ They settled down in the camp in March 2016. Greece was for most of the families a transition point before moving on to another European country.
} 
drawing, creative arts). In January 2017, the activities were integrated in the students' school program (for 11 weeks) and the project was completed with a theatrical performance by the children in front of their community and relatives back again in the camp. During the daily school program in RRTS, students participated in weekly 90-minute sessions, where a variety of drama techniques was used (see also Alkistis 2008; Baldwin 2008). The children were gradually getting more engaged in the project, as it was part of their weekly routine. Within a safe and respectful atmosphere, all the interventions were organized along the same pattern over eleven (11) weeks (Fig. 1), and the children's involvement and the topic complexity gradually increased as participants felt more comfortable and confident in their communication abilities.

\begin{tabular}{|c|c|c|c|}
\hline Week & Themes & Activities & Drama Techniques \\
\hline 1 & $\begin{array}{l}\text { Let's meet each } \\
\text { other }\end{array}$ & $\begin{array}{l}\text { Introduce each other using all } \\
\text { available resources (languages, } \\
\text { gestures, movements) }\end{array}$ & $\begin{array}{l}\text { Warm up games-getting to know } \\
\text { each other-trust games } \\
\text { Use of a persona doll (ELENI) } \\
\text { as mediator }\end{array}$ \\
\hline 2 & Hello \& goodbye & $\begin{array}{l}\text { - Greet/salute in many languages } \\
\text { - Use gestures to convey meaning } \\
\text { - Reproduce short sequences involving } \\
\text { salutations and names }\end{array}$ & $\begin{array}{l}\text { Role play, puppetry } \\
\text { Use of a persona doll (ELENI) } \\
\text { as mediator }\end{array}$ \\
\hline 3 & $\begin{array}{l}\text { Me, you and } \\
\text { others }\end{array}$ & $\begin{array}{l}\text { - Talk about myself, my family and my } \\
\text { life history } \\
\text { - Guess another person's identity } \\
\text { through pantomime and role playing }\end{array}$ & $\begin{array}{l}\text { Role play, puppets improvisation } \\
\text { from the facilitators and children } \\
\text { (animal, finger, giant puppets) }\end{array}$ \\
\hline 4 & $\begin{array}{l}\text { Let's express how } \\
\text { we feel }\end{array}$ & $\begin{array}{l}\text { - Express feelings through language, } \\
\text { body movements, gestures, facial } \\
\text { expressions, masks }\end{array}$ & $\begin{array}{l}\text { Pantomime, Freeze frames } \\
\text { Thought tracking, Working with } \\
\text { masks }\end{array}$ \\
\hline 5 & My own puppet!! & $\begin{array}{l}\text { - Make a puppet from recyclable } \\
\text { materials } \\
\text { - Invent physical and other } \\
\text { characteristics (age, gender, family, } \\
\text { likes/dislikes etc.) } \\
\text { - Make a story with the puppet } \\
\text { - Improvise a story with the puppet }\end{array}$ & $\begin{array}{l}\text { Warm up games } \\
\text { Use of a persona doll (Kosta) as } \\
\text { mediator } \\
\text { Puppetry making, improvisation } \\
\text { of the handmade puppets }\end{array}$ \\
\hline 6 & $\begin{array}{l}\text { When I grow up... } \\
\text { I will be... }\end{array}$ & - Talk about present/future plans & $\begin{array}{l}\text { Teacher in role, pantomime, } \\
\text { Role play }\end{array}$ \\
\hline 7 & $\begin{array}{l}\text { Let's play... with } \\
\text { animals }\end{array}$ & - Make short stories with animals & $\begin{array}{l}\text { Dramatization, Freeze Frames, } \\
\text { Thought tracking, Improvisation }\end{array}$ \\
\hline 8 & $\begin{array}{l}\text { Once upon a time I } \\
\text { (famous Greek tale) }\end{array}$ & $\begin{array}{l}\text { - Narrate a story } \\
\text { - Dramatize a story } \\
\text { - Make a short story } \\
\text { - Present events in chronological order }\end{array}$ & $\begin{array}{l}\text { Story Telling, Dramatization, } \\
\text { Freeze frames, Action clip }\end{array}$ \\
\hline
\end{tabular}




\begin{tabular}{|c|c|c|c|}
\hline 9 & $\begin{array}{l}\text { Once upon a time } \\
\text { II (Famous Arabic } \\
\text { tale) }\end{array}$ & $\begin{array}{l}\text { - Improvise a collectively made story } \\
\text { - Ask clarifications about situations, } \\
\text { processes and feelings } \\
\text { - Make short stories } \\
\text { - Present events in chronological order }\end{array}$ & $\begin{array}{l}\text { Teacher in role, dramatization, } \\
\text { Freeze frames, } \\
\text { Story telling with puppets }\end{array}$ \\
\hline 10 & $\begin{array}{l}\text { Let's celebrate } \\
\text { together }\end{array}$ & $\begin{array}{l}\text { - Improvise scenes from the story "The } \\
\text { Journey of Halima" in the children's } \\
\text { language repertoire }\end{array}$ & $\begin{array}{l}\text { Improvisation, Dramatization, } \\
\text { Tableau vivant, } \\
\text { Thought tracking }\end{array}$ \\
\hline 11 & $\begin{array}{l}\text { The journey begins } \\
\text {... }\end{array}$ & $\begin{array}{l}\text { - Perform in front of an audience in the } \\
\text { Camp } \\
\text { - Affirm our identity }\end{array}$ & Dramatization \\
\hline
\end{tabular}

Fig. 1: Content of activities

All tasks were purposeful, contextualized, and interactive. In Step 5, for instance, after the children had made their own puppets and introduced the specific character to the whole class, a small improvisation in pairs followed. In the same vein, after reading The Journey of Halima (Step 10) the 'tableau vivant' technique (still images, thought tracking) was used in order to unfold the story, reenact the story non-verbally, understand the characters' dilemmas as their own, and come up with their own solutions. During the role-plays the children interacted in a given context in order to achieve a specific communication goal.

\subsection{Procedure}

Every week, a different topic was presented to facilitate basic communicative needs in the Greek language. Topics related to the children's everyday lives, and activities included interactional tasks among children and the research team.

In most cases, drawing and painting, music and art were also used to support the drama activities. All the above allowed for the negotiation of meaning in the second language and the increase of creativity so as to enhance the children's performance skills in character development and storytelling and facilitate their active engagement in learning (Fig. 2 and 3).

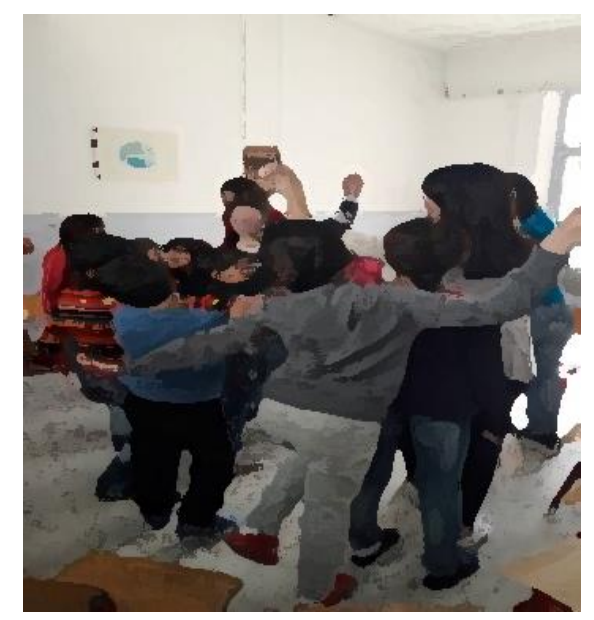

Fig. 2: Warm-up games 


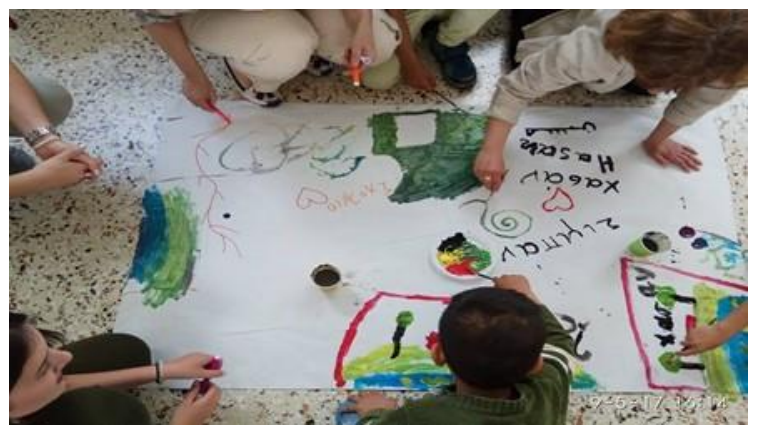

Fig. 3: Art team work

The members of the research team assumed the role of animators facilitating the learning process and encouraging the children to be creative and to express their own point of view, ideas and feelings (Fig. 4, 5 and 6).

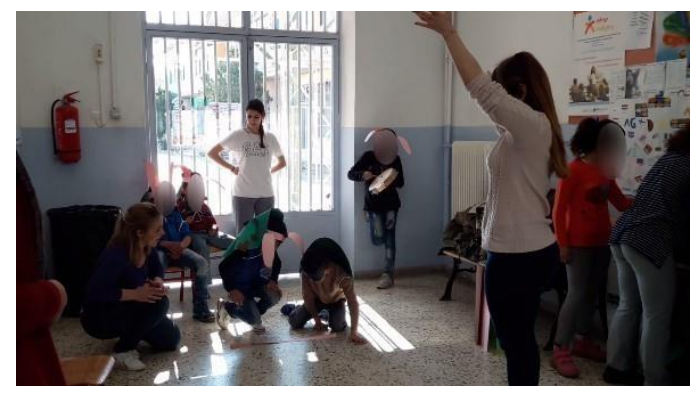

Fig. 4: Improvising the myth "The Hare and the Tortoise"

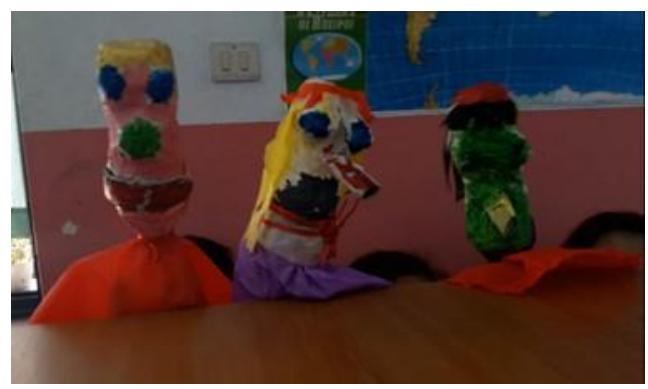

Fig. 5: Improvising with hand-made puppets

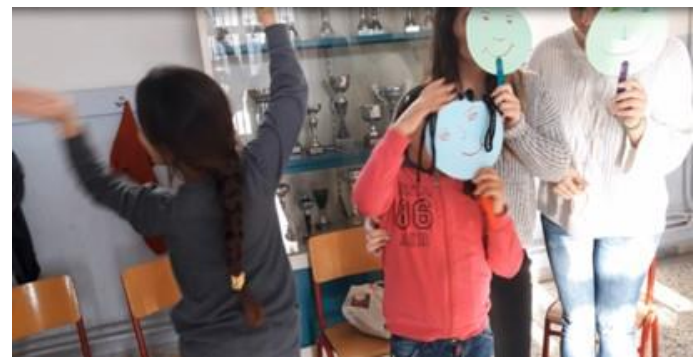

Fig. 6: Using facial masks to show feelings

In addition, most of the activities were conducted in pairs or groups and involved physical movement within the classroom. 


\subsection{Methodology-Data collection}

The project consisted of three phases, starting by specifying the needs of the children through participatory observation in the camp, so as to better define their sociolinguistic profile. Following we designed a flexible and adjusted to them curriculum including drama pedagogy and second language learning. Subsequent, the activities were implemented. On the final part, students were involved in metacommentaries on their experiences and reflections about the project through interviews. A parental consent form was used to gather permission from parents and guardians to let their child participate in the program and the research process.

The participant observation method (Gray 2014) was used to identify the communication processes through the drama sessions. An observation guide was constructed and filled in by the researchers during the activities. The observation notes included data regarding a) classroom interaction (the relationships in the class, the dynamics among peers and between students and the research team), b) language(s) used, and c) involvement in the drama activities (Luatti 2011). Moreover, most activities were videotaped and the recordings were used to further document data from the observation. Upon the completion of the project, semi-structured interviews with the children were conducted to understand how the children experienced their involvement in the project. The children were asked to express their opinion about the drama activities, to reflect on the skills they may have acquired during the project and to discuss the relationships with their classmates and the research team.

\section{Data Analysis}

Data from participant observation and semi-structured interviews were thematically analyzed (Marshall \& Rossman 2016). The data analysis started with a preliminary exploratory analysis. After the first coding process, the meanings created were related to each other and the codes for the chunks of data were reduced and collapsed in order to understand the central phenomenon through description and thematic development (Creswell 2007). Data were organized into thematic categories from both participant observations and interviews (Fig. 7 and 8):

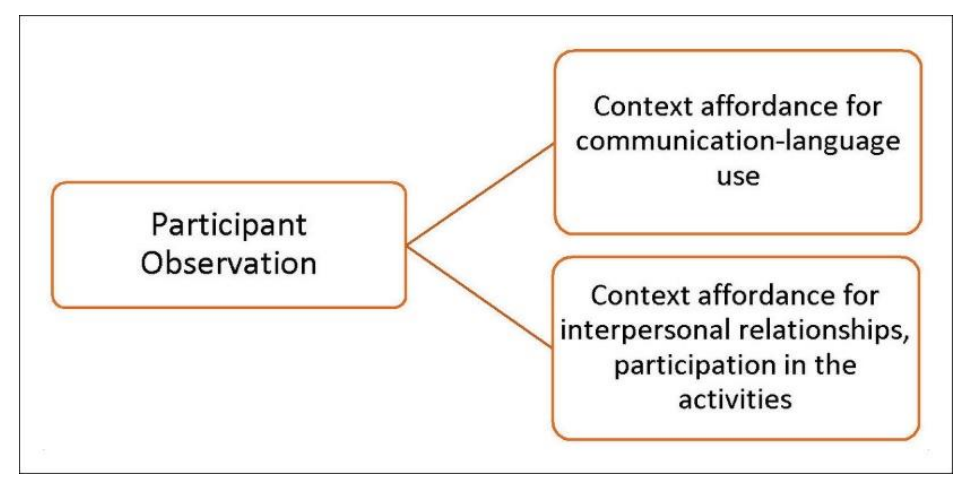

Fig. 7: Thematic categories from the participant observation 


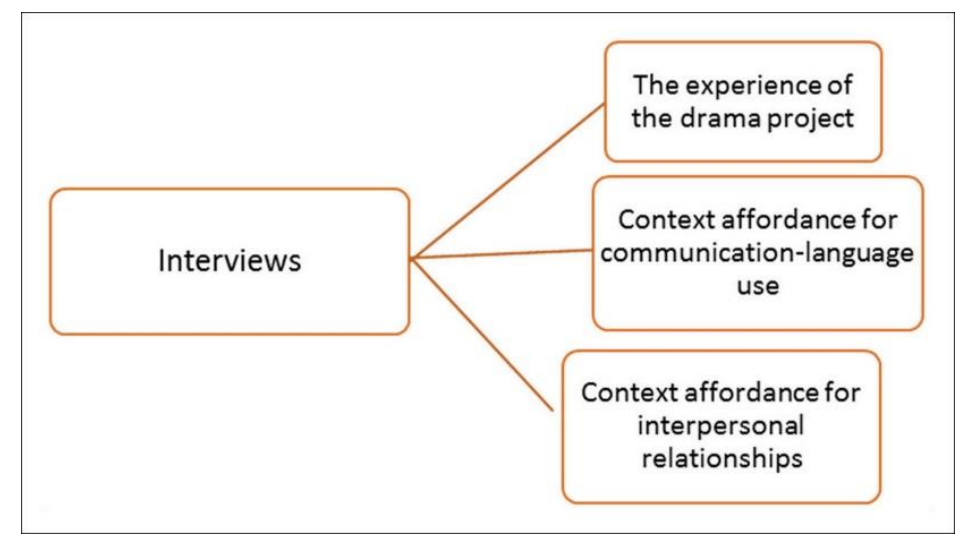

Fig. 8: Thematic categories from the interviews

\subsection{Findings from the Participant observation}

Analysis of the participant observations led to a multi-faceted understanding of Drama as a multimodal mode of communication and as a mode of facilitating the involvement in the learning process. The kinaesthetic orientation and multisensory stance of the project functioned as dynamic tools for self-expression, communication and second language learning.

\subsubsection{Context affordance for communication-language use}

During the drama sessions, the children made use of various representational modes to interact with their classmates and the research team such as facial expressions, gestures, eye contact, posture and tone of voice. The children activated processes of synaesthesia (Cope and Kalantzis 2009) and made use of all available resources (verbal and non-verbal) to construct meaning and to maximize their communicative potential. For example, they used gestures to convey meaning, facial expressions to explain likes and dislikes, body posture to represent feelings and characters and diversified voice tone to adjust to certain characters ${ }^{4}$.

One example: The frame of the interaction. Children are making objects for the dramatization of the fable 'The tortoise and the hare' (hare's ears and tortoise shells). S4 is decorating the hare's ears. She looks very engaged in the activity, picks another marker to continue her work. She has already designed a green star, a yellow flower, a red star and a rose heart. The teacher

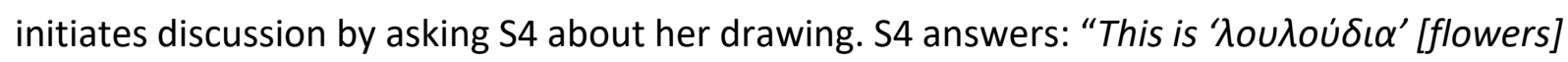

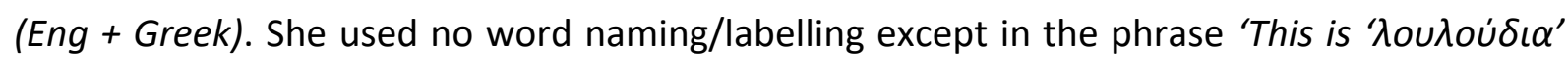
$(E n g+$ Greek). She made repetition of the clause 'this is...' in English (by her own initiative) however the phrase remains mostly unfinished (no predicate) as she wants to express herself in Greek. At the same time, she points to the sky to explain that she drew a star (deictic gesture) and she makes the sign of a heart with her hands (metaphoric). As far as the body

\footnotetext{
${ }^{4}$ More details are presented in Papadopoulou, Vitsou \& Gana (2018).
} 
posture is concerned, she has a directional position only for indexing interpretations regarding her sign making (uses both hands for the sign of the heart, points to the sky to locate the star). After making a symbolic sign (the heart), she stares the teacher wondering about the teacher's interpretation. Additionally, she displays a directional shift of the head along with a beat movement to manifest agreement and engagement in the conversation.

S4 appears fully engaged in the communication (full range of modes \& trans-modal synergy) the moment she makes the sign of the heart. In that instance, her multimodal choices could be associated with aspects of her identity (intercultural issues, school perceptions, etc.).

Although students were allowed to use all languages (native languages, Greek, English), they used the Greek quite often, a choice that reinforced learning of the Greek language. They also made extensive use of translanguaging practices.

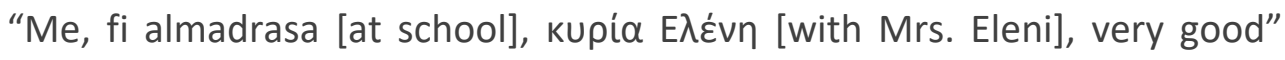 (Eng+Arabic+Greek)

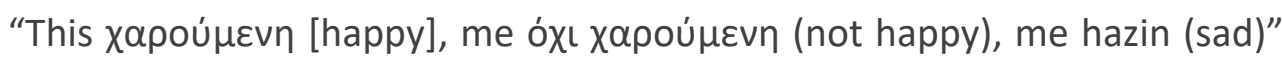 Eng+Greek+Arabic)}

Additionally, due to the fact that unlike typical school environments no explicit error correction was provided to the students, learners felt safe to express themselves in Greek during specific communication events-drama activities e.g. dramatization of a story.

Simultaneously, almost all children presented high competency in the "acting" during the drama conventions using verbal and non-verbal resources.

It is noteworthy that in the context of drama pedagogy the children were encouraged to use all their linguistic repertoires and to produce dialogues as in the case of the following excerpt, showing a puppetry improvisation based on "Little Red Riding Hood". The teacher starts narrating the story and two children improvise with their puppets (Fig. 9).

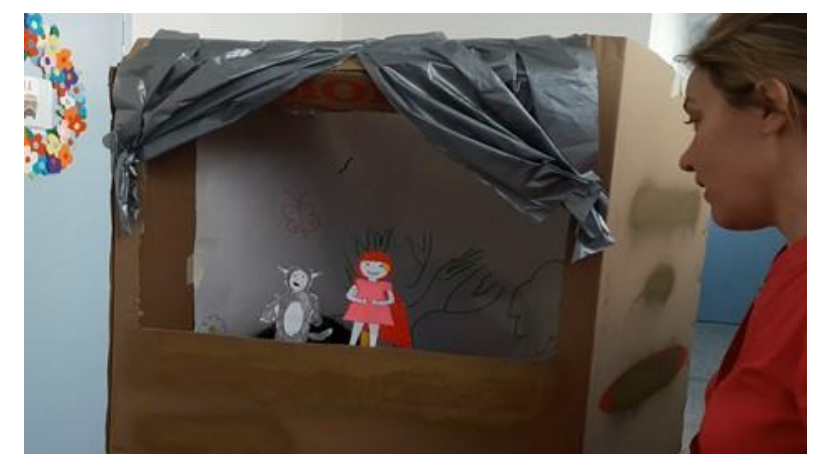

Fig. 9: Puppet improvising "Little Riding Hood" 


\author{
S1: Пoıos eival; [who is it?]

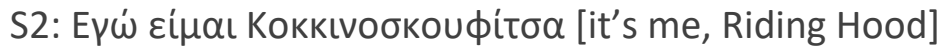

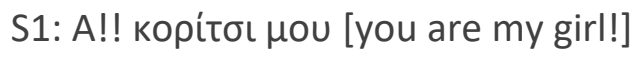

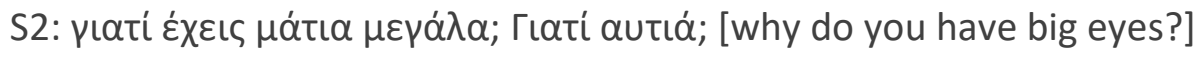 \\ S1: $\alpha$ коú $\mu \varepsilon$ [we listen]

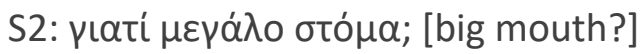

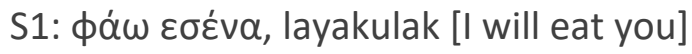

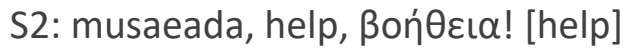

\title{
4.1.2 Context affordance for interpersonal relationships - Participation in the activities
} It should be underlined that participation in the program was voluntary. Usually, the children needed a period of 3-4 weeks to adjust and overcome their embarrassment and initial hesitation (especially the boys). Older boys' (9-12 years old) participation, though limited at the beginning, slowly increased. Furthermore, their initial non-participatory performance (standing as spectators/viewers of the activities, laughing at other students, clearly refusing to engage in activities that included physical expression with girls and the younger boys) gradually improved and they got actively involved in drama activities. The use of various strategies (such as teamwork) and positive attitude toward drama activities facilitated children's oral communication skills and oral expression. Additionally, after the warm-up activities group members seemed more comfortable to trust each other and interact in mixed groups (boys and girls) regardless of age or origin (Arabs-Kurds). A mutual respect and a sense of empowerment among the group members gradually developed.

Consequently, the communication with the tutors and student teachers improved and an atmosphere of trust was gradually established. Children progressively sought out physical contact with the university students (touching hair, giving hugs, establishing eye contact) and developed more personal relationships with them (gift exchange), with a strong interest for each student's personal life and preferences.

\subsection{Findings from the interviews}

\subsubsection{The experience of drama project}

According to data from the interviews at the end of the project, the participants positively appreciated their engagement in the project. Corporeality, use of artifacts and sense of community were positively described by the students, who argued that that the playful nature of the activities provided them with opportunities to express themselves and have fun: 


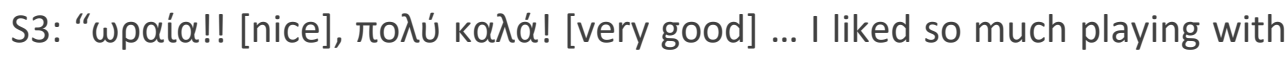
friends, girls [prospective teachers], to be in school with my friends"

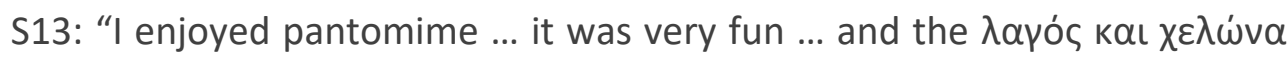

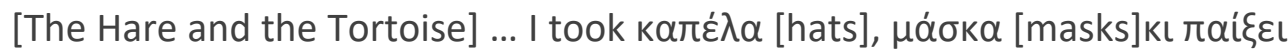

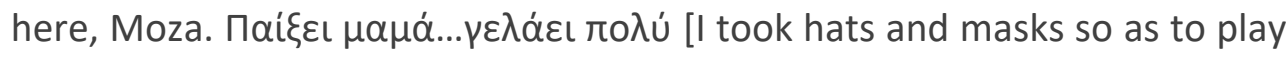
here (in their hosting structure ). I played and my mom laughed a lot]."

They admitted that drama helped them to share experiences about their life, their family, their countries and their relatives:

S6: "I am not intimidated now to play theatre with my friends and in front of others ... I am so happy with that..."

Moreover, the fact that they alternate roles (students become teachers) to "teach" their own cultural experiences seems to be an unprecedented and communicative empowering experience for students:

S15: "I taught [the] teachers' Kurdish words and songs from Syria ... I liked that ... I like talking about my house in Syria, the school and my families' customs."

Regarding the use of Persona Dolls as mediators, they indicated the strong bond with them and their preferences in puppetry making and animating:

S7: "I want to play theater every week! I love puppets, I like play with Kosta and Eleni [Persona dolls] ... it's very nice"

\subsubsection{Context affordance for communication-language use}

The children also appreciated the multilingual and multimodal dimension interrelated with the drama pedagogy in this project. Although the experience of hearing different languages in school seems unusual (at least in the Greek educational context), they valued positively that their languages of origin could be heard, and that they were able to express their cultural experiences:

S12: "we could use any language we wanted, Kurdish, Greek, English ... it was fun but I understood"

They also asserted that they were strengthen as interlocutors and that they enjoyed engaging in classroom communication because they were able to learn to speak Greek, and to communicate with all the participants. Meanwhile, they seemed to realize that in order to communicate in such a context they could use not only the dominant language (Greek), but all language repertoires and other resources: 
S7: "Even though I don't speak Greek well, they understood what I was saying...through pantomime, movements ... some English, some Kurdish ... some Greek. We used all languages together ... it was fun".

They were also proud of their performance in the Greek language and self-confident to communicate in Greek on several occasions:

S1: "I have learnt some Greek ... I understand better now at school ..."

S3: "When we go out in the city [Volos] for shopping I help my mom with Greek ... I teach my mom Greek words ... and I understand better now..."

Although the participants had no previous experience in similar courses, and some of them (boys, in particular) were at first reluctant to participate, they soon got engaged in the procedure and they participated with enthusiasm:

S9: "at the beginning I felt quite awkward ... I, a big boy to play in theatre ... but it wasn't as bad as I thought ..."

S16: "I enjoy playing theatre so much! I am looking forward for more theatre lessons ... in the camp."

\subsubsection{Context affordance for interpersonal relationships}

Regarding interaction with their classmates and tutors, the children expressed positive feelings and enthusiasm.

S7: “Altogether we played puppetry with our own puppets. It was so fun, no books, just play"

The strong bond, which was developed during the sessions, the identity affirmation, the feeling of acceptance and trust were of the outmost importance:

S17: "I am looking forward for seeing and playing with all the girls [university students], it's nice having lessons with them ... they are very good and helpful."

The collaboration during drama sessions, the group work and the final performance inside the Camp made them proud of themselves. Additionally, the positive response from the camp administration and the educational stakeholders encouraged them to be more engaged.

S4: "My mother and my father liked very much our drama play in Moza, they said 'Mтраßо [well done] S4 you did great at Greek school' [and] really enjoyed our drama play at the end of the school year ... all together we showed to our families what we did in the Greek school" [they performed in front of their families in the camp] (Fig. 10) 


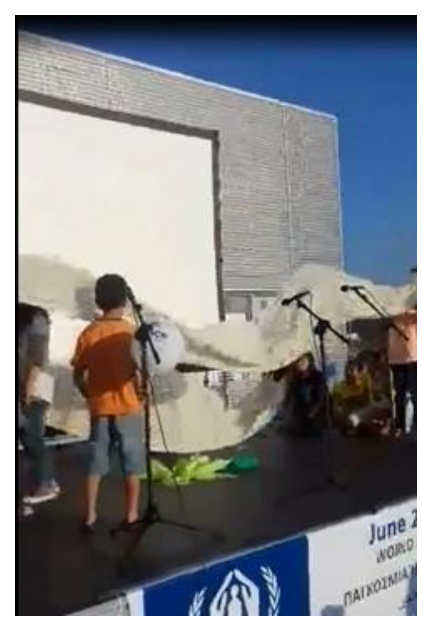

Fig. 10: Performing in front of an audience in the Camp

\section{Conclusion and discussion}

The research provided data from a case study to discuss the contribution of quality pedagogical experiences in the life of young refugee children in terms of promoting their communicational, and social-emotional development through a drama project. The findings not only reinforced this concept, but also indicated that drama activities can provide children with a safe space to constructively express their feelings and ideas in ways that encourage creativity and meaningful learning.

Furthermore, data gave insights on the ways drama activities along with situated practice can reinforce refugee children in school participation and second language learning (Vitsou, Papadopoulou \& Gana 2019; Papadopoulou, Tsioli \& Androulakis 2019). Drama techniques allowed for self-expression in many modes (facial and body expressions, gestures and gaze) and languages to convey meaning. Children had the opportunity to use their native language in school and engage in dialogues where all languages (Arabic, Kurdish, English and Greek) were used. Additionally, prior experiences were brought into the surface, the children were emotionally and linguistic empowered, and translanguaging was used to facilitate communication (Garcia \& Wei 2014). During drama activities the children were able to communicate with peers and tutors, improved their listening skills (following instructions, developing phonemic awareness, and understanding new words and phrases), developed strategies for interpreting new words (use of non-verbal language and translanguaging) and increased their ability for storytelling through drama.

Moreover, during the drama sessions the 'stress factor' was significantly decreased and therefore the children improved their communication skills in authentic and dynamic situations as it is proposed by Krashen (1988). This approach gave the students a more active role in the process by decentralizing the classroom and promoting a collaborative learning environment. Students went beyond the 'here and now' and even 'walked in somebody else's 
shoes'. Furthermore, they developed empathy, cultivated their intercultural skills and strengthened their identities. Working in groups made them more independent, confident and creative (Athiemoolam 2004; Chukueggu 2012; Cumming \& Visser 2009; Naoko 2006; Souki 2019).

In conclusion, it should be noted that education in emergencies has to consider refugee children's needs in their entirety and to address social and emotional issues involved in the learning processes. Meanwhile, language learning activities incorporating music, drama, theater or art can help young refugee children cope with trauma and fears (Delaney 2016; Frimberger 2016). In this vein, drama can be considered not only as an effective pedagogical method to facilitate communication (Ntelioglou et al. 2014), but also as a teaching procedure to make refugee children regain hope for the future (Papadopoulou et al. 2019).

\section{Bibliography}

Aden, Joëlle (2017): Developing empathy through theatre: A transcultural perspective in second language education. In: Schewe, Manfred \& Crutchfield, John (eds.): Going Performative in intercultural education. International contexts - theoretical perspectives - models of practice. Clevedon: Multilingual Matters, 59-81

Aden, Joëlle \& Pavlovskaya, Maria (2018): Translanguaging and Language Creativity in Drama Staging. In: Mazzaferro, Gerardo (ed.): Translanguaging as Everyday Practice. Dordrecht: Springer, 215233

Alkistis (2008): Mavri agelada-aspri agelada, Dramatiki Techni stin Ekpaidefsi kai Diapolitismikotita [Black cow-white cow, Drama in Education and Interculturality]. Athens: Topos

Athiemoolam, Logamurthie (2004): Drama in education and its effectiveness in English second/foreign language classes. Paper presented at The First International Language Learning Conference (illc), Universiti Sains Malaysia, Penang

Baldwin, Patrice (2008): The primary drama handbook: a practical guide for teaching assistants and teachers new to drama. Thousand Oaks, CA: SAGE Publications

Bengochea, Alain; Sembiante, Sabrina \& Gort, Mileidis (2018): An emergent bilingual child's multimodal choices in sociodramatic play. In: Journal of Early Childhood Literacy 18/1, 38-70, https://doi.org/10.1177/1468798417739081

Bräuer, Gerd (2002): Body and Language. Intercultural learning through drama. Westport, CT: Ablex Publishing

Cassity, Elizabeth \& Gow, Greg (2005): Shifting Space and Cultural Place: The transition experiences of African young people in west Sydney schools. Paper presented at the Australian Association of Educational Research Annual Conference, Sydney 
Christie, Pam \& Sidhu, Ravinder (2006): Governmentality and Fearless Speech: Framing the education of asylum seeker and refugee children in Australia. In: Oxford Review of Education 32/4, 449-465, http://dx.doi.org/10.1080/03054980600884177

Chukueggu, Chioma O.C. (2012): The use of drama and dramatic activities in English language teaching. In: The Crab: Journal of Theatre and Media Arts 7, 151-159, http://crab.uniport.edu.ng/images/crabjournal download/The\%20Use\%20of\%20Drama\%20and\% 20Dramatic\%20Activities\%20in\%20English\%20Language\%20Teaching.pdf [last accessed November 7, 2019]

Cope, Bill \& Kalantzis, Mary (2009): Multiliteracies: New literacies, new learning. In: Pedagogies: An international journal 4/3, 164-195, https://doi.org/10.1080/15544800903076044

Creswell, W. John (2007): Qualitative inquiry and research design: Choosing among five approaches (2nd ed.). Thousand Oaks, CA: Sage

Culham, Cameron (2002): Coping with obstacles in drama-based ESL teaching: A nonverbal approach. In: Bräuer, Gerd (eds.): Body and Language. Westport, CT: Ablex Publishing, 95-112

Cumming, Stevi \& Visser, John (2009): Using art with vulnerable children. In: Support for Learning 24/4, 151-157, https://doi.org/10.1111/j.1467-9604.2009.01418.x

Delaney, Marie (2016, July 21). Can learning languages help refugees cope?

https://www.britishcouncil.org/voices-magazine/can-learning-languages-help-refugees-cope [last accessed_October 13, 2018]

Desiatova, Liubov (2009): Using different forms of drama in EFL Classroom: Humanizing language teaching. In: Magazine 4, https://old.hltmag.co.uk/aug09/sart07.htm. [last accessed November 15, 2019]

Dryden-Peterson, Sarah (2017): Refugee Education: Education for an Unknowable Future. In: Curriculum Inquiry 47/1, 14-24, https://doi.org/10.1080/03626784.2016.1255935

Franks, Anton (2014): Drama and the representation of affect - structures of feeling and signs of learning. In: Research in Drama Education. The Journal of Applied Theatre and Performance 19/2, 195-207, https://doi.org/10.1080/13569783.2014.895614

Frimberger, Katja. (2016). Towards a well-being focussed language pedagogy: enabling arts-based, multilingual learning spaces for young people with refugee backgrounds. In: Pedagogy, Culture \& Society 24/2, 285-299, https://doi.org/10.1080/14681366.2016.1155639

Galante, Angelica \& Thomson, Ron (2017): The Effectiveness of Drama as an Instructional Approach for the Development of Second Language Oral Fluency, Comprehensibility, and Accentedness. In: Tesol Quarterly 51/1, 115-142, https://doi.org/10.1002/tesq.290

García-Mateus, Suzanne \& Palmer, Deborah (2017): Translanguaging Pedagogies for Positive Identities in Two-Way Dual Language Bilingual Education. In: Journal of Language, Identity \& Education 16/4, 245-255, https://doi.org/10.1080/15348458.2017.1329016

García, Ofelia \& Kleifgen, Jo Anna (2018): Educating Emergent Bilinguals: Policies, Programs, and Practices for English Learners. New York: Teachers College Press 
García, Ofelia \& Wei, Li (2014): Translanguaging: Language, Bilingualism and Education. New York: Palgrave Macmillan

Gray, David (2014): Doing Research in the Real World. London: Sage

Hos, Rabia (2014): Caring is not enough: Teachers' Enactment of Ethical Care for Adolescent Students with Limited or Interrupted Formal Education (SLIFE) in a Newcomer Classroom. In: Education and Urban Society 48/5, 479-503, https://doi.org/10.1177/0013124514536440

Hos, Rabia (2016): Education in Emergencies: Case of a Community School for Syrian Refugees. In: European Journal of Educational Research 5/2, 53-60, https://doi.org/10.12973/eu-jer.5.2.53

Jalbout, Maysa (2015). Partnering for a Better Future: Ensuring Educational Opportunity for All Syrian Refugee Children and Youth in Turkey. Their World briefing,

http://theirworld.org/resources/detail/briefing-building-a-better-future [last accessed November $28,2019]$

Krashen, Stephen (1988): Second Language Acquisition and Second Language Learning. New Jersey: Prentice-Hall International

Larsen-Freeman, Diane (1990): On the need for a theory of language teaching. In: Alatis, James (ed.): The interdependence of theory, practice and research; Georgetown University roundtable on languages and linguistics. Washington, DC: Georgetown University Press, 261-270

Luatti, Lorenzo (eds.) (2011): Observing in order to understand and operate in multicultural classes. The Notebook of Inte(g)ra(c)tion in Italian and European schools: Portfolio of Integration: the European experience, https://www.gla.ac.uk/media/Media 327320 smxx.pdf [last accessed November 28, 2019]

Maley, Alan \& Duff, Alan (2005): Drama Techniques. A resource book of communication activities for language teachers. Cambridge: Cambridge University Press

Marshall, Catherine \& Rossman, Gretchen (2016): Designing Qualitative Research. SAGE: Thousand Oaks

Naoko, AAraki-Metcalfe (2006): The waterhole: using educational drama as a pedagogical tool in a foreign language class at a public primary school in Japan, PhD thesis, Faculty of Education, University of Melbourne

Ntelioglou, Burcu Yaman (2011): 'But why do I have to take this class?' The mandatory drama-ESL class and multiliteracies pedagogy. In: Research in Drama Education. The Journal of Applied Theatre and Performance 16/4, 595-615, https://doi.org/10.1080/13569783.2011.617108

Ntelioglou, Burcu Yaman; Fannin, Jennifer; Montanera, Mike \& Cummins, Jim (2014): A multilingual and multimodal approach to literacy teaching and learning in urban education: a collaborative inquiry project in an urban inner city elementary school. In: Front. Psychol. 5/533, https://doi.org/10.3389/fpsyg.2014.00533

Papadopoulou, Maria; Tsioli, Sofia \& Androulakis, George (2019): A cocriação de espaços seguros e coloridos através do aprendizado informal para crianças refugiadas [Co-creating safe and colorful spaces through informal learning for refugee children]. In: Ferreira, Corrêa; Perna, Cristina; 
Gualda, Ricardo \& Leurquin, Eulalia Vera Lucia Fraga (eds.): Língua de acolhimento: Experiências no Brasil e no Mundo. Belo Horizonte - Minas Gerais: Mosaico, 207-230,

http://www.letras.ufmg.br/padrao cms/documentos/profs/luciane/capa linguadeacolhimentoEB OOK\%20DEFINITIVO.pdf [last accessed November 28, 2019]

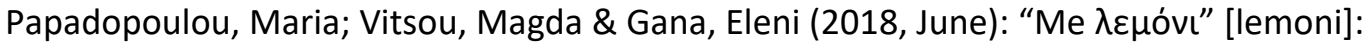

Communication practices of children refugees in a project of Literacy through Drama. Oral Presentation at the 5th International Conference 'Crossroads of Languages and Cultures', Centre for Intercultural and Migration Studies of the Department of Primary Education/CERS of the University of Crete, Greece

Phillips, Sarah (2003): Drama with children. Oxford: Oxford University Press

Scientific Committee in Support of Refugee Children (2017), Assessment Report on the Integration Project of Refugee Children in Education, Ministry of Education, Research \& Religious Affairs, Athens, available at: https://www.minedu.gov.gr/public ations/docs2017/CENG Epistimoni ki Epitropi Prosfygon YPPETH Ap otimisi Protaseis $2016 \quad 2017 \quad 070 \quad$.pdf

Sinclair, Margaret (2007): Education in Emergencies. Commonwealth Education Partnerships. http://www.cedol.org/wp-content/uploads/2012/02/52-56-2007.pdf [last accessed March 15, 2016]

Souki, El Ghenwa (2019). Using the Visual Arts to Support the Development of Young Refugee Children: A Puppet-Making Workshop. Thesis, Georgia State University, 2019.

https://scholarworks.gsu.edu/art design theses/249. [last accessed September 10, 2019]

Vitsou, Magda \& Papadopoulou, Maria (2019): Ekpaidefsi meso ethelontikis drasis:symmetoxi fititrion se ena programma grammatismou paidion prosfygon me texnikes tis dramatikis texnis stin ekpaidefsi [Volunteer education: teacher student participation in a literacy program for

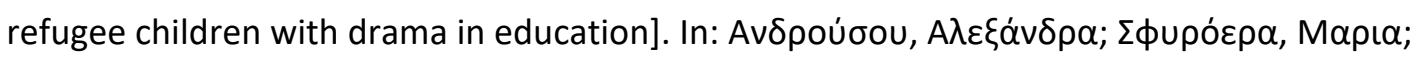

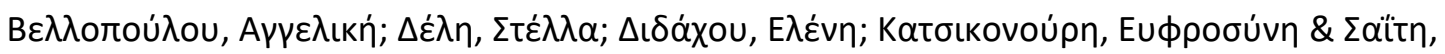

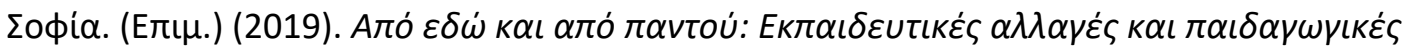

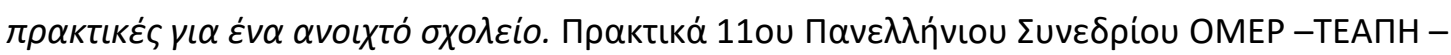

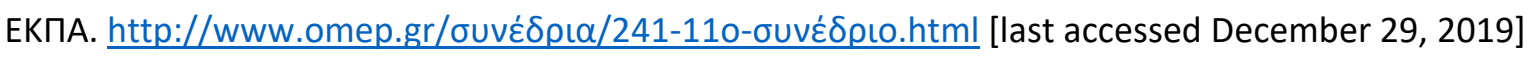

Vitsou, Magda \& Papadopoulou, Maria \& Gana, Eleni (2019): Drama Pedagogy for Refugee Children: Means for Empowerment and Communication. In: Babylonia [Fondazione Lingue e Culture] 3, 4449.

Yun, Seongwon (2008): Role-play and language socialization among bilingual Korean children in the United States. In: Simulation Gaming 39/2, 240-252, https://doi.org/10.1177/1046878107310614 